\title{
Assessment of People's Awareness and Perception of Flooding in Donga Town, Taraba State, Nigeria
}

\author{
Kehinde T. Oyatayo ${ }^{1}$, Godwin A. Songu1 ${ }^{1}$, Timothy A. Adi ${ }^{1}$, Godwill G. Jidauna², \\ Christopher Ndabula ${ }^{2}$ \\ ${ }^{1}$ Department of Geography, Kwararafa University, Wukari, Nigeria \\ ${ }^{2}$ Department of Geography and Regional Planning, Federal University Dutsin-Ma, Dutsin-Ma, Nigeria \\ Email: "kehindeoyatayo@gmail.com
}

Received 16 December 2015; accepted 9 May 2016; published 12 May 2016

Copyright (C) 2016 by authors and Scientific Research Publishing Inc.

This work is licensed under the Creative Commons Attribution International License (CC BY). http://creativecommons.org/licenses/by/4.0/

(c) (i) Open Access

\begin{abstract}
Flooding is now an annual occurring event in Donga Town especially after heavy rainstorm which is further worsened by the nature of the topography of the area. The knowledge of how the public view flooding is considered a crucial aspect in modern flood management as it steers the development of effective and efficient flood mitigation strategies. This study therefore assessed public perception of flooding in Donga town. Two wards were purposively drawn out of ten wards (Gata Aure and Fada ward). The survey design method was employed in this study. Yamane (1967) method of sample size determination was used to arrive at a sample size of 130 for the study. Systematic random sampling was used in the administration of 130 questionnaires to respondents. Non parametric statistics of Spear Man rank correlation and descriptive statistics (percentages, tables, pie and bar charts) were used to analyze the data. The result of the findings showed that $95 \%$ of the respondents were male, $88.4 \%$ of the respondents were aware that the area was prone to flooding. Also, about $46.2 \%$ perceived that rainfall was the major cause of flooding in the study area. Correlation analysis result was insignificant which implied that in Donga town, educational level of respondents did not influence respondent's awareness level of flooding and that people's perception of flooding was influenced by factors other than respondent's literacy level. The conclusion from the study is that rainfall intensity and amount is the main cause of flooding in Donga town and also individual's response to flooding in the study area is poor. This study recommends the need to educate the people living in the flood plain on the dangers of continuous occupation of the area.
\end{abstract}

\section{Keywords}

Perception, Awareness, Flooding, Preparedness, Town

\footnotetext{
${ }^{*}$ Corresponding author.
}

How to cite this paper: Oyatayo, K.T., Songu, G.A., Adi, T.A., Jidauna, G.G. and Ndabula, C. (2016) Assessment of People's Awareness and Perception of Flooding in Donga Town, Taraba State, Nigeria. Journal of Geoscience and Environment Protection, 4, 54-62. http://dx.doi.org/10.4236/gep.2016.45006 


\section{Introduction}

Flooding is one of the most common and widely distributed natural risks to life and property worldwide. It has a special place in natural hazards and accounts for approximately one third of all natural disasters in both developed and developing world [1]. Flooding is also responsible for more than half of all related fatalities and a third of the economic loss from all natural catastrophes. The reason for this as observed by [2] lies in the widespread geographical distribution of river flood plains and low lying coast, together with their long standing attraction for human settlement.

Flooding is a general or temporary condition of partial or complete inundation of normally dry areas of land from overflow of inland or tidal waters or from unusual and rapid accumulation or runoff of surface waters from any source land [3]. According to [4], factors contributing to the frequency and severity of flooding include: Rainfall intensity and duration; antecedent moisture condition; watershed conditions, including steepness of terrain, soil types, amount of vegetation, and density of development, changes in landscape resulting from wild fires (loss of moisture trapping vegetation and increased sediment available for runoff); the existence of attenuating features, such as levees and flood control channel; velocity of flow; availability of sediment for transport, and the erodibility of the bed and banks of the water course.

Following the first World Summit on Sustainable Development in Rio de Janeiro and the adoption of Agenda 21 in 1992, a progressive shift occurs that considers disaster mitigation a crucial component for loss reduction and a crosscutting issue and requisite for sustainable social, economic, environmental, and humanitarian development [5]. The notion of flood perception refers to the intuitive judgments of individuals and social groups in the context of limited and uncertain information. These judgments vary between individuals due to different levels of information and uncertainty, due to different intuitive behavior, and also due to specific power constellations and positions of interest [6]. [7] defines flooding perception as people's point of view of flooding which is influenced by their level of awareness, potential exposure and experience with flooding.

Public perception of flooding is often overlooked when developing flood management plans. Perception of flood at both the individual and public level represents a key societal component in flood management that is integral to determine the response to flood warnings and efforts to increase community preparedness. Previous flood management policies have been known to fail or be adversely affected when policy makers overlook the subjective and highly contextualized nature of public perception [8] [9].

As a consequence, the individuals of a community may assess their flood risk very differently, because they do not have the same information about their risk status, about flood mitigation measures and their effectiveness, and they perhaps have a different historical background regarding the experience of living in a floodplain and of being flooded. In the face of the very diverse flooding perceptions within society, a communication process on flooding should be encouraged as a basis for policy. If prevailing perceptions and value concepts become transparent and open to public debate, a common perception of communities may evolve and contribute to an increased acceptance of flood mitigation and management policies [6].

This study is therefore going to pay emphasis on the assessment of people's demographic and socio-economic characteristics, awareness about and perceived causes of flooding, as a measure to help enhance the mitigation and management of floods in Donga, as previous flood management policies have been known to fail or be adversely affected when policy makers overlook the subjective and highly contextualized nature of public perception and awareness.

\section{The Study Area}

\subsection{Location}

Geographically, Donga lies within latitude 70'43"N of the equator and longitude 10E of the meridian with the land area of approximately 58 square kilometers. It is located in the in the southern Taraba, bounded on the Northeast by kurmi Local Government Area, on the Northwest by Bali Local Government, to the Southwest Wukari Local Government Area, while to the Southeast by Takum Local Government Area. Donga has ten (10) political wards namely: Fada, GyataAure, Gndindutse, Mararaba, Kadarko, Akate, Suntai, Asibity, Gayama and Nyita Ward. See Figure 1 and Figure 2 for location of the study area [10].

\subsection{Climate}

The area has two marked seasons, the dry and the rainy season. The dry season starts from November to Mach 


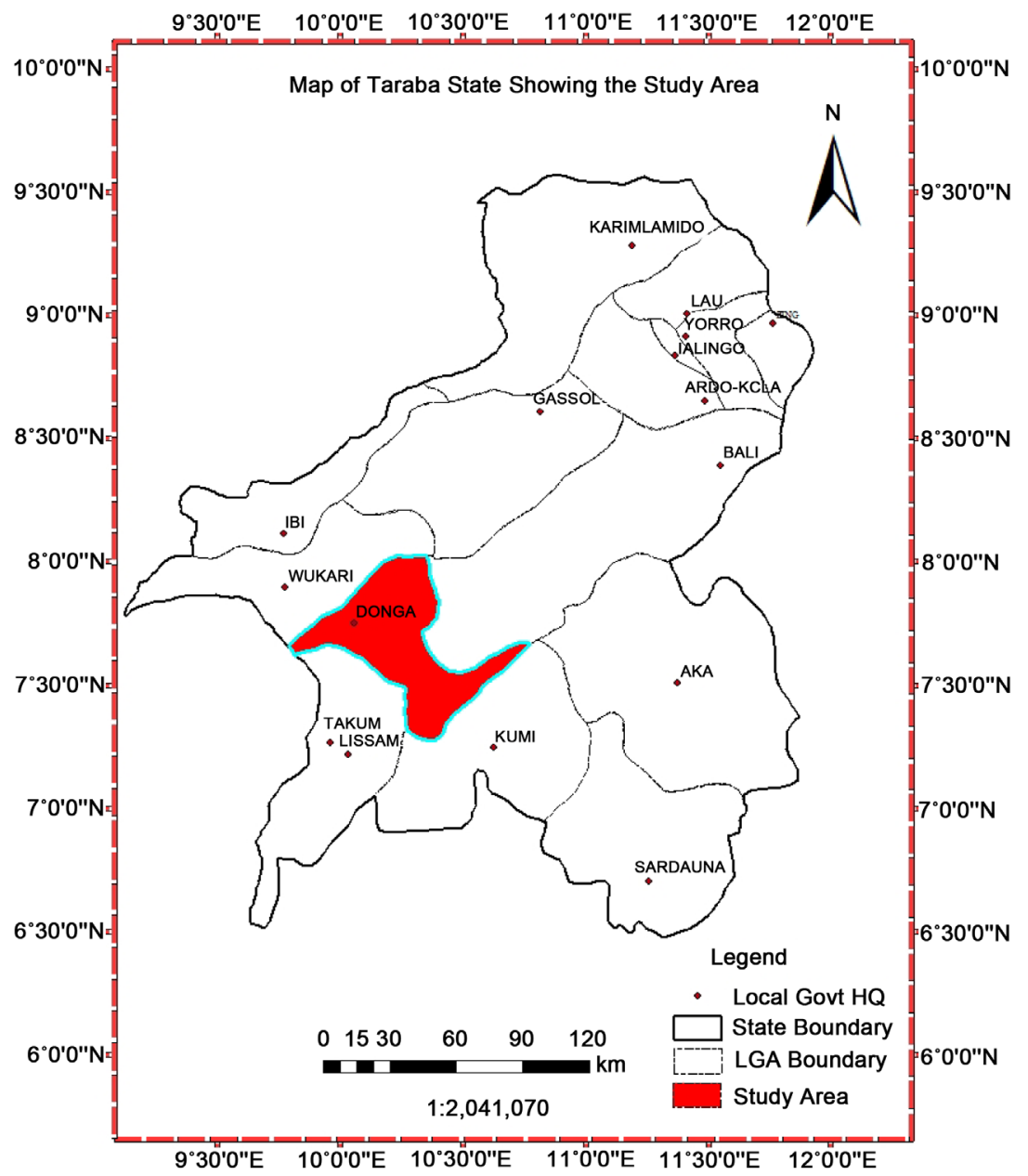

Figure 1. Map of Taraba State showing Wukari local government area. Source: Ministry of Lands and Survey, Jaligo, Tarba State.

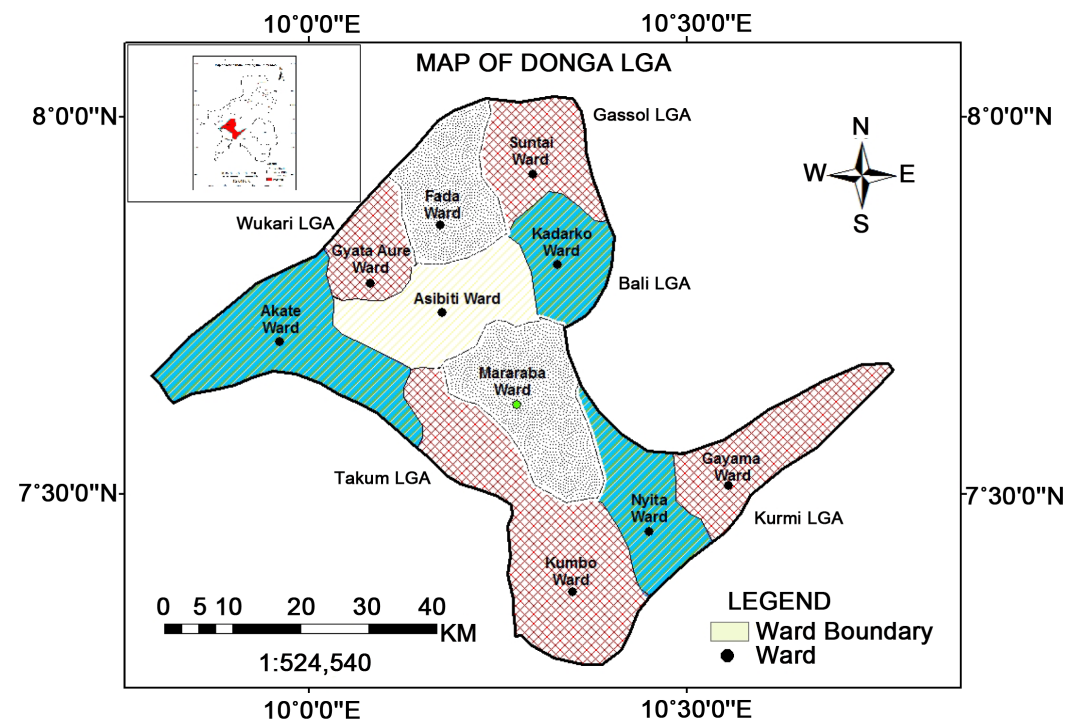

Figure 2. Map of donga local government area showing study area. Source: Ministry of Lands and Survey, Jaligo, Tarba State. 
while the rainy season from April to October. The temperature is generally high with mean annual temperature at $32^{\circ} \mathrm{C}$ recorded in April and low temperature can be as low as $10^{\circ} \mathrm{C}$ experienced in December January, but the mean minimum annual temperature is $22^{\circ} \mathrm{C}$ [10].

\subsection{Geology and Soil}

Donga is underlain by sedimentary rock of post Cambrian land era, and mainly consists of gentle undulating land with plains. It has a river and the basin constitutes one of the fertile arable lands of the mid region of Nigeria. The hilly undulating land stands at an altitude of 120 - 130 meters above sea level [10].

\subsection{Vegetation}

Donga Local Government falls within the woodland savannah zone a distinct type of vegetation, which is a transition between forest and savannah vegetation type. Thus there are both varieties of forest and savannah vegetation in which natural plant cover consist of trees, shrub and grasses, some of them loose there leaves for only short period in the year. A forest variety such as oil palm is formed scattered all over the area [10].

\subsection{Population}

Donga Local Government Area has diverse ethnic groups which include Chamba, Ichen, Kpanzun, Hausa, Tiv and Fulani. According to 2006 Census Figure released by National Population Commission (NPC), Donga Local Government Area amounted to population of about 134,111 people [10].

\section{Materials and Methods}

\subsection{Sampling Technique and Sample Size}

Considering the nature of the study, the size of the population as well the resources available for this research, the purposeful sampling method was used to divide the study area into identifiable units for the purpose of selecting samples. The local government has 10 wards and two wards were purposely sampled for this study. The reason was that the two council wards are more endemic in times of flooding, than any other council ward in the area. The two wards are: Gyata Aure and Fada wards.

A representation sample with known confidence and risk level was selected, based on the work of [11]. Based on this, 95\% confidence level and an error limit of 10\% were adopted.

The formula used by Yamane [11] goes thus:

$$
n=\frac{N}{1+N(e)^{2}}
$$

where

$n=$ required responses.

$\mathrm{e}^{2}=$ error limit.

$N=$ sample size.

We arrived at 100 questionnaires. To account for possible attrition, the number of subjects was increased to 130. The systematic random sampling was used in the administration of 130 questionnaires in the sampled wards. A total of 121 questionnaires were retrieved out of a total of 130 administered.

\subsection{Method of Data Analysis}

\section{Percentage}

$$
P=f / N \times 100 \%
$$

where:

$P=$ Percentage.

$F=$ Frequency to be converted to percentage.

$N=$ Numbers of frequencies.

Data obtained was analyzed via statistical (Spear Man rank correlation analysis) and descriptive statistics such as percentages and tables. 


\subsection{Statistical Analysis}

To examine public awareness and perception of flooding in Donga town, Donga local Government Area of Taraba State, the following hypotheses were postulated:

H0: there is no significant relationship between respondent's educational status and their level of awareness of flooding in Donga town.

H0: There is no significant relationship between respondent's perception of flooding and their level of education in Donga town.

This analysis was done with the aid of the Statistical Package for Social Sciences (SPSS).

\section{Result and Discussion}

This section present and analyses the data that were collected through the administration of questionnaire in the study area.

\subsection{Socio-Demographic Characteristics of Respondents}

The demographic data shows that $95 \%$ of the sampled respondents are male, while $5 \%$ are female as shown in Table 1. This disparity in gender proportion could be due to religious reasons as the study area is predominantly inhabited by Muslims. Under this religious understanding women are difficult to come by as Islam prohibits married women interacting freely with men.

Table 2 shows that $2.5 \%$ of the respondents are within the ages of 10 - 20 years, $28.1 \%$ were between 21 - 30 years, 31.4\% between 31 - 40 years, 19\% between 41 - 50 years and $19 \% 50$ years and above. This corroborates the findings of [12] in Jalingo, which asserts that majority of Jalingo dwellers were of the age bracket $24-40$ years.

Table 3 shows that 33\% of the respondents attended only primary school, 29\% attended secondary School, 21\% attended tertiary institution. $2 \%$ had informal education and $4 \%$ vocational education. This confirms the findings of [13] which are supportive of the fact that a large proportion of Makurdi dwellers attended primary, secondary and tertiary institutions.

Table 4 shows the occupational status of the respondent. 26\% of the respondents are engaged in fishing and farming, $18 \%$ are engaged in Trading/ Business, $16 \%$ are Artisans/craftsmen, and $13 \%$ are Civil servants. Based on field observation, most of the respondents are engaged in two (2) occupations. This confirms the finding of [12] which asserts that majority of the inhabitants of Jalingo metropolis are Farmers and Civil Servants.

\subsection{Level of Awareness of Respondents}

Table 5 indicates that $11.6 \%$ are slightly aware of flooding, $88.4 \%$ are strongly aware of flooding in the area. This finding corroborates that of [12] which is supportive of the fact that majority of floodplain dwellers in Jalingo were aware of flooding before moving into the area, some were not.

\subsection{Duration of Respondents Stay in the Study Area}

The question sought to ascertain how long the respondents have lived in the study area for those who have lived long will appreciate the flood problem better. This is to ensure that the respondent have a reasonable idea of the extent of flooding. 19\% have lived between 1 - 10 years, 22.3\% 11 - 20 years, 22.3\% 21 - 30 years, 19\% 31 - 40 year, 8.3\% 41 - 50 years and 9.1\% 51 years and above. These findings are similar to that of [12] which is supportive of the fact that inhabitants of Jalingo floodplain have reasonable idea of the flooding problem in Jalingo metropolis because they have lived for some time in the floodplain (Table 6).

\subsection{The Major Causes of Flooding in Donga}

Table 7 shows that there are many causes of flooding in the study area. Rainfall accounts for $46.2 \%$ of the cause of flooding, proximity to the main river accounts for $45.5 \%$ and low land area accounts for $8.3 \%$ of the cause of flooding. This finding is similar to that of [14], who conducted a flood risk assessment and management in Niger Delta Region of Nigeria. He noted that flood can be caused by heavy rainfall, highly accelerated snowmelt, severe winds over water, unusual high tide, tsunamis or failure of dams, levees, retention ponds or other structures that 
Table 1. Gender of the respondent.

\begin{tabular}{ccc}
\hline Variables & Frequency & Percentage (\%) \\
\hline Male & 115 & $96 \%$ \\
Female & 6 & $5 \%$ \\
Total & $\mathbf{1 2 1}$ & $\mathbf{1 0 0}$ \\
\hline
\end{tabular}

Source: field survey 2015.

Table 2. Age group of the respondents.

\begin{tabular}{ccc}
\hline Age Group & Frequency & Percentage \\
\hline $10-20$ & 3 & 2.5 \\
$21-30$ & 34 & 28.1 \\
$31-40$ & 38 & 31.4 \\
$41-50$ & 23 & 19 \\
51 above & 23 & 19 \\
Total & 121 & 100 \\
\hline
\end{tabular}

Source: field survey 2015.

Table 3. Educational status of the respondents.

\begin{tabular}{ccc}
\hline Variables & Frequency & Percentage (\%) \\
\hline Information & 15 & 12.4 \\
Primary & 40 & 33.1 \\
Secondary & 35 & 29 \\
Tertiary & 26 & 21.5 \\
Vocational & 5 & 4 \\
\hline
\end{tabular}

Source: field survey 2015.

Table 4. Occupation of the respondents.

\begin{tabular}{ccc}
\hline Variables & Frequency & Percentage (\%) \\
\hline Trading/business & 22 & 18 \\
Farming & 32 & 26.4 \\
Fishing & 31 & 26 \\
Artisan/craftsman & 20 & 16.5 \\
Civil servant & 16 & $13 . i$ \\
Total & $\mathbf{1 2 1}$ & $\mathbf{1 0 0}$ \\
\hline
\end{tabular}

Source: field survey 2015.

Table 5. Level of awareness.

\begin{tabular}{ccc}
\hline Level of awareness & Frequency & Percentage (\%) \\
\hline Not aware & - & - \\
Slightly aware & 14 & 11.6 \\
Strongly aware & 107 & 88.4 \\
Total & $\mathbf{1 2 1}$ & $\mathbf{1 0 0}$ \\
\hline
\end{tabular}

Source: field survey 2015. 
Table 6. Duration of respondents stay in study area.

\begin{tabular}{ccc}
\hline Duration (Years) & Frequency & Percentage (\%) \\
$1-10$ & 23 & 19 \\
$11-20$ & 27 & 22.3 \\
$21-30$ & 27 & 22.3 \\
$31-40$ & 23 & 19 \\
$41-50$ & 10 & 8.3 \\
51 above & 11 & 9.1 \\
Total & $\mathbf{1 2 1}$ & $\mathbf{1 0 0}$ \\
\hline
\end{tabular}

Source: field survey 2015.

Table 7. Perceived causes of flooding.

\begin{tabular}{ccc}
\hline Causes & Frequency & Percentage (\%) \\
\hline Proximity to the main river & 55 & 45.5 \\
Land use & - & - \\
Low land area & 10 & 8.3 \\
Rainfall & 56 & 46.2 \\
Total & 121 & 100
\end{tabular}

Source: field survey 2015.

retained the water. Flooding can be exacerbated by increased amounts of impervious surface or by other natural hazards such as wildfires which reduce the supply of vegetation that can absorb rainfall. [15] cited in: [16] observes that rainfall intensity, duration and amount are generally believed to be the principal factors in most flood events in the tropics which are partly or wholly climatological in nature. Other factors only aided the incidence of flooding in urban areas of Nigeria. This has been confirmed by several studies cited in [16]-[19].

\subsection{Result of Statistical Analysis}

H0: There is no significant relationship between respondent's educational status and their level of awareness of flooding in Donga.

Statistical analyses using spear Man correlation coefficient analysis indicates that the calculated value ( $\mathrm{r}$ calculated) is 0.051 and the critical value is 0.950 at 0.05 level of significance and 2 degree of freedom. Hence, we accept the null hypothesis which states that there is no significant relationship between respondent's educational status and their level of awareness of flooding in Donga town. It means that educational attainment of respondents does not influence respondent's awareness of flooding in the study area. The finding is similar to that of [20].

H0: There is no significant relationship between respondent's perception of flooding and respondents level of education in Donga town.

Statistical analyses using spear Man rank correlation coefficient analysis shows that the calculated value ( $\mathrm{r}$ calculated) is 0.890 and the critical value is 0.950 at 0.05 level of significance and 2 degree of freedom. Hence, we accept the null hypothesis which states that there is no significant relationship between respondent's perception of flooding and respondent's educational status in Donga town. The finding is similar to that of [20]. This implies that in Donga town people's perception of flooding is influenced by factors other than literacy level.

\section{Conclusion}

This study has assessed the public perception of people on flooding in the study area. The study findings show 
that although majority of the floodplain dwellers are aware of flooding in the study area before moving into the area, some are not. The study shows that many have evacuated their residence and shops to flooding in the past. The conclusion is that despite the relatively high level of flood perception in the study area, individual's response to flooding in the study area by way of flood preventive and mitigation measures is very poor. Also, from the findings of the research, the conclusion is that the major cause of flooding in Donga town is rainfall intensity and amount. The conclusion from here is that in Donga town, people's educational level does not influence their awareness level of flooding. Also in Donga town, people's perception of flooding is influenced by factors other than respondent's literacy level.

\section{Recommendations}

The following are recommendations for future planning and implementation:

1) Programs promoting the use of traditional knowledge should be encouraged in order to exploit the local resources. It should also be noted that traditional knowledge on forecasting cannot function independently. It needs to be supported by warning methods and a wider range of support and risk management measures.

2) Donga community needs to embrace nonstructural measures that are low cost and have low maintenance requirements that are ultimately more sustainable. However, this does not necessarily diminish the importance of structural measures; rather it points to the necessity of combining structural and non-structural measures in a way that minimizes loss and achieve the best results.

\section{References}

[1] UNISDR (2012) United Nations International Strategy for Disaster Reduction. http://www.unisdr.org

[2] Agusomu, T.D. (2013) The Perception of and Response to Flood in the Niger Delta Basin of Nigeria. Unpublished Ph.D. Thesis, Department of Geography and Planning, University of Jos, Jos.

[3] Sharma, R.K. and Sharma, T.K. (2000) A Textbook of Hydrology and Water Resources Engineering. 5th Edition, DhanpatRai Publications (P) Ltd., New Delhi.

[4] Price, J.G., Hastings, J.T. and Arrit, M.C. (2007) Assessment of Risks and Vulnerability to Flood Hazards in Nevada. Nevada Bureau of Mines and Geology Open File Report 07-02. A Nevada Bureau of Mines and Geology, University of Nevada, Reno.

[5] UN/ISDR (2004) Living with Risk: A Global Review of Disaster Reduction Initiatives. United Nations Inter-Agency Secretariat of the ISDR (UN/ISDR), Geneva.

[6] Messner, F. and Meyer, V. (2005) Flood Damage, Vulnerability and Risk Perception—Challenges for Flood Damage Research. UFZ-Diskussionspapiere, No. 13/2005.

[7] Oyatayo, K.T. (2015) Assessment of Flood Vulnerability in Makurdi, Benue State, Nigeria. A Ph.D. Proposal Submitted to Geography Department, Ahmadu Bello University, Zaria.

[8] Granger-Morgan, M. (1995) Public Perception, Understanding and Values. In: Richards, D.J., Ed., The Industrial Green Game: Implications for Environmental Design into Management, National Academy Press, Washington DC, 200-2011.

[9] Brown, J.D. and Damery, S.L. (2002) Managing Flood Risk in the UK: Towards an Integration of Social and Technical Perspectives. Transactions of the Institute of British Geographers, 27, 412-426. http://dx.doi.org/10.1111/1475-5661.00063

[10] Enoch, B. (2001) History of Donga Local Government. Donga Educational Books, Donga, 1-End.

[11] Yamane, T. (1967) Statistics: An Introductory Analysis. 2nd Edition, Harper and Row, New York.

[12] Oruonye, E.D. (2012) An Assessment of Food Risk Perception and Response in Jalingo Metropolis. Jaingo Taraba State. International Journal of Forest, Soil and Erosion, 3, 4-12.

[13] Ahile, S.I. and Andityavyar, E.M. (2014) Household Perception and Preparedness against Flooding in Makurdi Town, Benue State, Nigeria. IOSR Journal of Environmental Science, Toxicology and Food Technology, 8, 1-6.

[14] Ologunorisa, T.E. (2006) Flood Risk Assessment and Management in Nigeria: Perspective from the Niger Delta. Selfer Education Books, Makurdi, 1-End.

[15] Ayoade, J.O. (1988) Tropical Hydrology and Water Resources. MacMilan Publishers, Ibadan.

[16] Ocheri, M. and Okele, E. (2012) Social Impact and People’s Perception of Flooding in Makurdi Town, Nigeria. Special Publication of the Nigerian Association of Hydrological Sciences. Nigerian Association of Hydrological Sciences, Nigeria, 97-105. 
[17] Omiunu, F.G. (1981) Ogunpa Flood Disaster: An Environmental Problem or Cultural Fiction, Aman, 110-120.

[18] Oriola, E.O. (2000) Flood and Flood Management. In: Jimoh, H.I.J., Ed., Contemporary Issues on Environmental Management, Haytee Press, Ibadan, 100-109.

[19] Etuonovbe, A.K. (2011) The Devastating Effect of Flooding in Nigeria, Hydrography and Environment, TS06J, Epworth, Zimbabwe.

[20] Aboagye, D., Dari, T. and Koomson, J. (2013) Risk Perception and Disaster Management in the Savannah reGion of Ghana. International Journal of Humanities and social Science, 3, 84-96. 